\title{
Soybean response to nitrogen application across the United States: A synthesis-analysis
}

\author{
Spyridon Mourtzinis ${ }^{\mathrm{a}, *}$, Gurpreet Kaur ${ }^{\mathrm{b}}$, John M. Orlowski ${ }^{\mathrm{b}}$, Charles A. Shapiro ${ }^{\mathrm{c}}$, Chad D. Lee ${ }^{\mathrm{d}}$, \\ Charles Wortmann ${ }^{\mathrm{c}}$, David Holshouser ${ }^{\mathrm{e}}$, Emerson D. Nafziger ${ }^{\mathrm{f}}$, Hans Kandel ${ }^{\mathrm{g}}$, Jason Niekamp ${ }^{\mathrm{f}}$, \\ William J. Ross ${ }^{\mathrm{h}}$, Josh Lofton ${ }^{\mathrm{i}}$, Joshua Vonk ${ }^{\mathrm{f}}$, Kraig L. Roozeboom ${ }^{\mathrm{j}}$, Kurt D. Thelen ${ }^{\mathrm{k}}$, \\ Laura E. Lindsey ${ }^{1}$, Michael Staton ${ }^{\mathrm{m}}$, Seth L. Naeve ${ }^{\mathrm{n}}$, Shaun N. Casteel ${ }^{\mathrm{o}}$, William J. Wiebold ${ }^{\mathrm{p}}$, \\ Shawn P. Conley ${ }^{\mathrm{a}}$
}

${ }^{a}$ Department of Agronomy, University of Wisconsin-Madison, Madison, WI 53706, USA

b Delta Research and Extension Center, Mississippi State University, Stoneville, MS 38776, USA

c Department of Agronomy and Horticulture, University of Nebraska-Lincoln, Lincoln, NE 68583-0915, USA

d Department of Plant and Soil Sciences, University of Kentucky, Lexington, KY 40546-0312, USA

e Department of Crop and Soil Environmental Sciences, Virginia Tech, Blacksburg, VA 24061, USA

${ }^{\mathrm{f}}$ Department of Crop Sciences, University of Illinois, Urbana, IL 61801, USA

g Department of Plant Sciences, North Dakota State University, Fargo, ND 58108-6050, USA

h Department of Crop, Soil, and Environmental Sciences, University of Arkansas System Division of Agriculture, Little Rock, AR 72204, USA

i Department of Plant and Soil Sciences, Oklahoma State University, Stillwater, OK 74074, USA

${ }^{j}$ Department of Agronomy, Kansas State University, Manhattan, KS 66506-0110, USA

${ }^{\mathbf{k}}$ Department of Plant, Soil \& Microbial Sciences, Michigan State University, East Lansing, MI 48824, USA

${ }^{1}$ Department of Horticulture and Crop Science, The Ohio State University, Columbus, OH 43210, USA

$m$ Michigan State University Extension, Allegan, MI 49010, USA

${ }^{n}$ Department of Agronomy and Plant Genetics, University of Minnesota, St. Paul, MN 55108, USA

o Department of Agronomy, Purdue University, West Lafayette, IN 47907, USA

P Division of Plant Sciences, University of Missouri, Columbia, MO 65211, USA

\section{A R T I C L E I N F O}

\section{Keywords:}

Soybean

Nitrogen

Hierarchical model

Regression tree

\begin{abstract}
A B S T R A C T
The effects of supplemental nitrogen (N) on soybean [Glycine max (L.) Merr.] seed yield have been the focus of much research over the past four decades. However, most experiments were region-specific and focused on the effect of a single N-related management choice, thus resulting in a limited inference space. Here, we composited data from individual experiments conducted across the US that examined the effect of $\mathrm{N}$ fertilization on soybean yield. The combined database included 207 environments (experiment $\times$ year combinations) for a total of 5991 $\mathrm{N}$-treated soybean yields. We used hierarchical modeling and conditional inference tree analysis on the combined dataset to establish the relationship and contribution of several $\mathrm{N}$ management choices on soybean yield. The $\mathrm{N}$ treatment variables were: $\mathrm{N}$-application (single or split), $\mathrm{N}$-method (soil incorporated, foliar, etc.), $\mathrm{N}$ timing (pre-plant, at a reproductive stage, etc.), and N-rate (from a $0 \mathrm{~N}$ control to as much as $560 \mathrm{~kg} \mathrm{ha}^{-1}$ ). Of the total yield variability, $68 \%$ was associated with the effect of environment, whereas only a small fraction of that variability $(<1 \%$ ) was attributable to each $\mathrm{N}$ variable. Averaged over all experiments, a single $\mathrm{N}$ application and the split $\mathrm{N}$ application were 60 and $110 \mathrm{~kg}^{-1}$ greater yielding than the zero $\mathrm{N}$ control treatment, respectively. A split $\mathrm{N}$ application with more than one method (e.g., soil incorporated and foliar) resulted in $120 \mathrm{~kg} \mathrm{ha}^{-1}$ greater yield than zero N plots. Split N application between planting and reproductive stages (Rn) resulted in greater yield than zero $\mathrm{N}$ and single application during a Rn; however, the effect was not significantly different than $\mathrm{N}$ application at other growth stages. Increasing the $\mathrm{N}$ rate increased the environment average soybean yield; however, $93 \%$ of the environment-specific N-rate responses were not significant which suggested a minimal effect of $\mathrm{N}$ across the examined region. A large yield variability was observed among environments
\end{abstract}

\footnotetext{
Abbreviations: BNF, biological nitrogen fixation; C, check (no nitrogen was applied); MM, major management practices; N, nitrogen; N-rate, nitrogen rate; N-application, number of

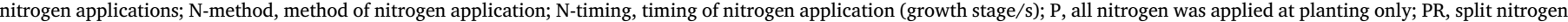

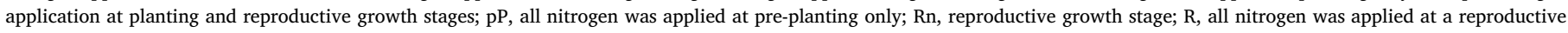
growth stage only; RR, split nitrogen application at two reproductive growth stages; V, all nitrogen was applied at a vegetative growth stage only; Vn, vegetative growth stage

* Corresponding author.

E-mail address: mourtzinis@wisc.edu (S. Mourtzinis).
} 
within the same $\mathrm{N}$ rates, which was attributed to growing environment differences (e.g., in-season weather conditions, soil type etc.) and non-N related management (e.g., irrigation). Conditional inference tree analysis identified $\mathrm{N}$-timing and $\mathrm{N}$-rate to be conditional to irrigation, and to seeding rates $>420,000$ seeds ha $^{-1}$, indicating that $\mathrm{N}$ management decisions should take into account major, non- $\mathrm{N}$ related management practices. Overall, the analysis revealed that $\mathrm{N}$ management decisions had a measurable, but small, effect on soybean yield. Given the growing pressure for increasing food production, it is imperative to further examine all soybean $\mathrm{N}$ decisions (application method, timing, and rate) in environment- and cropping system-specific randomized trials in important agricultural regions.

\section{Introduction}

Soybean [Glycine max (L.) Merr.] is the most important oilseed crop in the USA, grown mainly as a protein and oil source for animal and human consumption. USA soybean production has increased by $60 \%$ from 1996 to 2016 . The increase in soybean production is due to a $30 \%$ increase in area planted to soybean, and to better genetics and improved crop management practices that have resulted in a 35\% increase in mean soybean seed yield $\left(2,600-3,500 \mathrm{~kg} \mathrm{ha}^{-1}\right.$ between 1996 and 2016; USDA-NASS, 2017). While these historic seed yield increases have been substantial, USA soybean producers continually search for opportunities to optimize crop management and increase soybean seed yield, including applying fertilizer $\mathrm{N}$ to soybean.

Soybean has a large nutrient requirement throughout the growing season, and has an especially high $\mathrm{N}$ requirement due to its seed protein content that averages about $40 \%$ based on seed dry weight (Bellaloui et al., 2015). Analysis of 637 data sets, (site $\times$ year $\times$ treatment combinations) from 1966 to 2006, indicates a linear increase in N uptake in soybean aboveground biomass of $0.079 \mathrm{~kg}$ with each $\mathrm{kg}$ increase in seed yield (Salvagiotti et al., 2008). In a recent study conducted at multiple locations in Wisconsin and Minnesota, $\mathrm{N}$ content of soybean increased by $0.054 \mathrm{~kg}$ with each $\mathrm{kg}$ increase in seed yield (Gaspar et al., 2017). Soybean N requirements peak in the R3 to R6 growth stages (Harper and Cooper, 1971; Harper, 1974). Gaspar et al. (2017) reported that maximum daily $\mathrm{N}$ uptake rates $\left(3.6-4.3 \mathrm{~kg} \mathrm{ha}^{-1} \mathrm{~d}^{-1}\right.$ ) occur during the R4 to R5 (Fehr and Caviness, 1977) growth stages, whereas Bender et al. (2015) measured a greater daily $\mathrm{N}$ uptake rate of $4.6 \mathrm{~kg} \mathrm{ha}^{-1}$ at $\mathrm{R} 4$ growth stage.

The $\mathrm{N}$ requirement of soybean is generally fulfilled by biological nitrogen fixation (BNF) plus $\mathrm{N}$ uptake from soil (Salvagiotti et al., 2008). Salvagiotti et al. (2008) reported that $50-60 \%$ of soybean $N$ demand is fulfilled by BNF, whereas Harper (1974) found that 25 to $60 \%$ of $\mathrm{N}$ in soybean plants comes from BNF and the remaining 40 to $75 \%$ is provided from soil. Comparatively, greater contribution from BNF of near $90 \%$ (to seed $\mathrm{N}$ content) and $97 \%$ (to total plant $\mathrm{N}$ uptake) was reported by Mastrodomenico and Purcell (2012) and George et al. (1988), respectively. Zapata et al. (1987) concluded that maximum BNF occurs between the R1 and R4 stages, and biologically-fixed N (55\%) contributes more to $\mathrm{N}$ assimilation in pods and seeds by the R7 growth stage compared to soil $\mathrm{N}(43 \%)$.

Based on lack of response to supplemental $\mathrm{N}$ applications, Freeborn et al. (2001) concluded that N supply through BNF and soil organic matter mineralization is sufficient for high soybean yields. However, BNF activity can be limited by a number of environmental conditions such as low soil moisture, extremes of soil $\mathrm{pH}$ and temperature, and soil compaction, any of which can result in insufficient $\mathrm{N}$ supply to the soybean plants (Purcell and King, 1996). Cold and saturated soil early in the growing season can slow the mineralization of organic matter and thus limit soil N availability to soybeans (Stanford et al., 1973; Stanford and Epstein, 1974). Maximum N mineralization rates occur when soil is at field capacity (0.3-0.1 bar matric suction), whereas saturated soils reduce $\mathrm{N}$ accumulation due to gaseous $\mathrm{N}$ losses by the denitrification process (Stanford and Epstein, 1974). Additionally, $\mathrm{N}$ mineralization increases when the temperature rises from 10 to $25^{\circ} \mathrm{C}$ (Agehara and Warncke, 2005). Stanford et al. (1977) reported a two- fold change in mineralization rate with a $10^{\circ} \mathrm{C}$ shift in soil temperature. The quantity of soil $\mathrm{N}$ mineralized is also directly related to the organic $\mathrm{N}$ amount available in the soil. Although $\mathrm{N}$ may be limited early in the growing season, studies report that $\mathrm{N}$ supply by BNF during podfilling (R4-R6) may lag behind $\mathrm{N}$ demand in high-yielding soybean (Wesley et al., 1998). Thibodeau and Jaworski (1975) reported that maximum BNF occurs at the early pod fill stage and again when seed development occurs at maximum rates. The high nitrogen requirement for soybean seed growth demands continued remobilization of $\mathrm{N}$ from vegetative tissues (Sinclair and de Wit, 1975), which reduces photosynthetic capacity of leaves and accelerates leaf senescence, and can restrict duration of the seed-fill period which thus reduces seed yield potential. Any gap between soybean $\mathrm{N}$ demand and $\mathrm{N}$ supply by BNF thus needs to be supplied via other $\mathrm{N}$ sources in order to reduce the gap between the realized soybean seed yield and its potential. One strategy for closing this gap is the application of $\mathrm{N}$ fertilizer to soybean, particularly when the crop is subjected to adverse growing conditions or produced in high-yield environments.

Extensive research to date has documented the impacts of $\mathrm{N}$ fertilizer source, application rate, application method, and seasonal timing on USA soybean yield. Many of these studies show inconsistent response of soybean yield to $\mathrm{N}$ application within and across states. For example, $\mathrm{N}$ applications of $50 \mathrm{~kg} \mathrm{ha}^{-1}$ at planting resulted in $8 \%$ increase in soybean seed yield in Alabama (Starling et al., 1998), and a $12 \%$ increase in soybean yield in Kansas when N (22-45 kg ha ${ }^{-1}$ ) was applied at R3 stage (Wesley et al., 1998). In an earlier study, Brevedan et al. (1978) observed a $28-32 \%$ increase in soybean seed yield in Kentucky, which the authors attributed to increased nodes plant ${ }^{-1}$, seeds plant ${ }^{-1}$, and seed mass, plus decreased flower and pod abortion. In two different studies conducted in Mississippi on clay soil, soybean seed yield was increased by $8 \%$ with $90-179 \mathrm{~kg} \mathrm{~N} \mathrm{ha}^{-1}$ irrespective of application at V4 or R1 (McCoy, 2016), and by 15\% with 260-360 $\mathrm{kg} \mathrm{N} \mathrm{ha}^{-1}$ when applied during early vegetative growth (Vn) (Ray et al., 2006). In Nebraska, soybean yields increased by $5 \%$ when fertilized with $180 \mathrm{~kg} \mathrm{~N} \mathrm{ha}^{-1}$ compared to unfertilized soybeans (Salvagiotti et al., 2009). In other studies in Nebraska, differences in test site soil $\mathrm{pH}$, soil organic matter, yield level, irrigation, and residual soil nitrate content resulted in inconsistent soybean response to $\mathrm{N}$ application between years (Sorensen and Penas, 1978; Al-Ithawi et al., 1980). These results highlight the challenge in predicting the conditions favorable for, and the magnitude of, soybean yield response to $\mathrm{N}$ applications.

Influence of initial soil nitrate- $\mathrm{N}$ content on soybean response to $\mathrm{N}$ fertilizations also has been reported in previous studies (Stone et al., 1985; Lamb et al., 1990; Wood et al., 1993; Scharf and Wiebold, 2003). In Missouri studies, a small yield response to $\mathrm{N}$ application (33 $\mathrm{kg} \mathrm{ha}^{-1}$ ) was observed only on soils with soil $\mathrm{pH}<6$ and nitrate-N content $<$ $56 \mathrm{~kg} \mathrm{ha}^{-1}$ in the top $61 \mathrm{~cm}$ depth (Scharf and Wiebold, 2003). Lamb et al. (1990) and Stone et al. (1985) observed that soybean responded to $\mathrm{N}$ fertilizer only when soil nitrate-N content was $<90 \mathrm{~kg} \mathrm{ha}^{-1}$ (0-61 cm soil depth) and $<190 \mathrm{~kg} \mathrm{ha}^{-1}(0-180 \mathrm{~cm}$ soil depth), respectively. Similarly, Stone et al. (1985) found that for each $1 \mathrm{~kg} \mathrm{ha}^{-1}$ increase in soil nitrate- $\mathrm{N}$ content, the soybean yield benefit from $\mathrm{N}$ fertilization decreased by $4 \mathrm{~kg} \mathrm{ha}^{-1}$. High levels of soil $\mathrm{N}$ (application rate of $90-200 \mathrm{~kg} \mathrm{ha}^{-1}$, or a $4-7.5 \mathrm{mM}$ soil nitrate concentration) 
inhibited nodule formation and suppressed BNF throughout the season, leading to a decreased or similar seed yield when compared to unfertilized soybeans (Harper, 1974; Harper and Gibson, 1984; Lamb et al., 1990). However, other researchers have suggested that $\mathrm{N}$ fertilizer placement below the root nodulation zone could be an option to mitigate BNF inhibition by N fertilizer (Harper and Cooper, 1971; Salvagiotti et al., 2009).

A number of researchers have reported on soybean yield response to $\mathrm{N}$ fertilizer application timing, $\mathrm{N}$ source, and $\mathrm{N}$ placement. Beard and Hoover (1971) reported that early-season N applications reduced nodule numbers compared to late-season $\mathrm{N}$ application, resulting in decreased seed yield. Wood et al. (1993) concluded that applying $\mathrm{N}$ fertilizer at R5 was more reliable for increasing seed yield than applying at R1. However, no differences in seed yield were reported for N application at early flowering or pod filling (Welch et al., 1973), nor at V4 and R3 (McCoy, 2016). Barker and Sawyer (2005) found no differences in soybean seed yield due to $\mathrm{N}$ source (polymer coated urea [PCU] or urea) and $\mathrm{N}$ placement (broadcast or banded) in Iowa, as did Osborne and Riedell (2006b) for ammonium nitrate or urea, Welch et al. (1973) for organic or inorganic fertilizers, Wesley et al. (1998) for urea ammonium nitrate (UAN), ammonium nitrate (AN), urea, urea + NBPT ( $N$-(n-butyl) thiophosphoric triamide) urease inhibitor, and Schmitt et al. (2001) for urea or PCU. Similarly, Salvagiotti et al. (2009) found no difference in soybean yields between PCU (pre-plant applied at $20 \mathrm{~cm}$ below soil surface) and applications of ammonium nitrate, either as split between pre-plant and V6, or as a single surface application at R5. In contrast, McCoy (2016) observed 2.5\% greater seed yield with PCU compared to urea + NBPT in Mississippi. Welch et al. (1973) found that $\mathrm{N}$ application method (plow-down, disked-in, side-dressed) had no effect on soybean seed yield for $\mathrm{N}$ application at either early flowering or pod-filling stage in Illinois.

The variation observed in soybean yield responses to $\mathrm{N}$ fertilizer applications at various test sites and years in the United States in the reviewed literature may have been due to differences in soybean cultivars, soil properties (initial soil $\mathrm{N}$ content, textures, soil temperature, $\mathrm{pH}$, moisture, other nutrients), climatic conditions (rainfall, air temperature) during the growing season, topography, and crop management practices such as irrigation, tillage, crop rotation, and planting time (Osborne and Riedell, 2006a). Because a single study was not conducted at multiple USA locations for several years, it is difficult to draw general conclusions about $\mathrm{N}$ management effects on soybean seed yield. We postulated that a combined analysis of data from multiple soybean $\mathrm{N}$ fertilization studies across multiple locations and years would facilitate a deeper understanding of management effects on soybean seed yield. Thus, the objectives of this study were to examine the effects of $\mathrm{N}$ fertilizer in terms of $\mathrm{N}$-application number (single or split applied), $\mathrm{N}$-method (soil surface, soil incorporated, foliar, or a combination of these), N-timing (pre-plant, at-planting, Vn or Rn growth stages, or combination of these), and N-rate on soybean seed yield across the USA.

\section{Materials and methods}

\subsection{Data description}

Soybean yield data were aggregated from replicated field

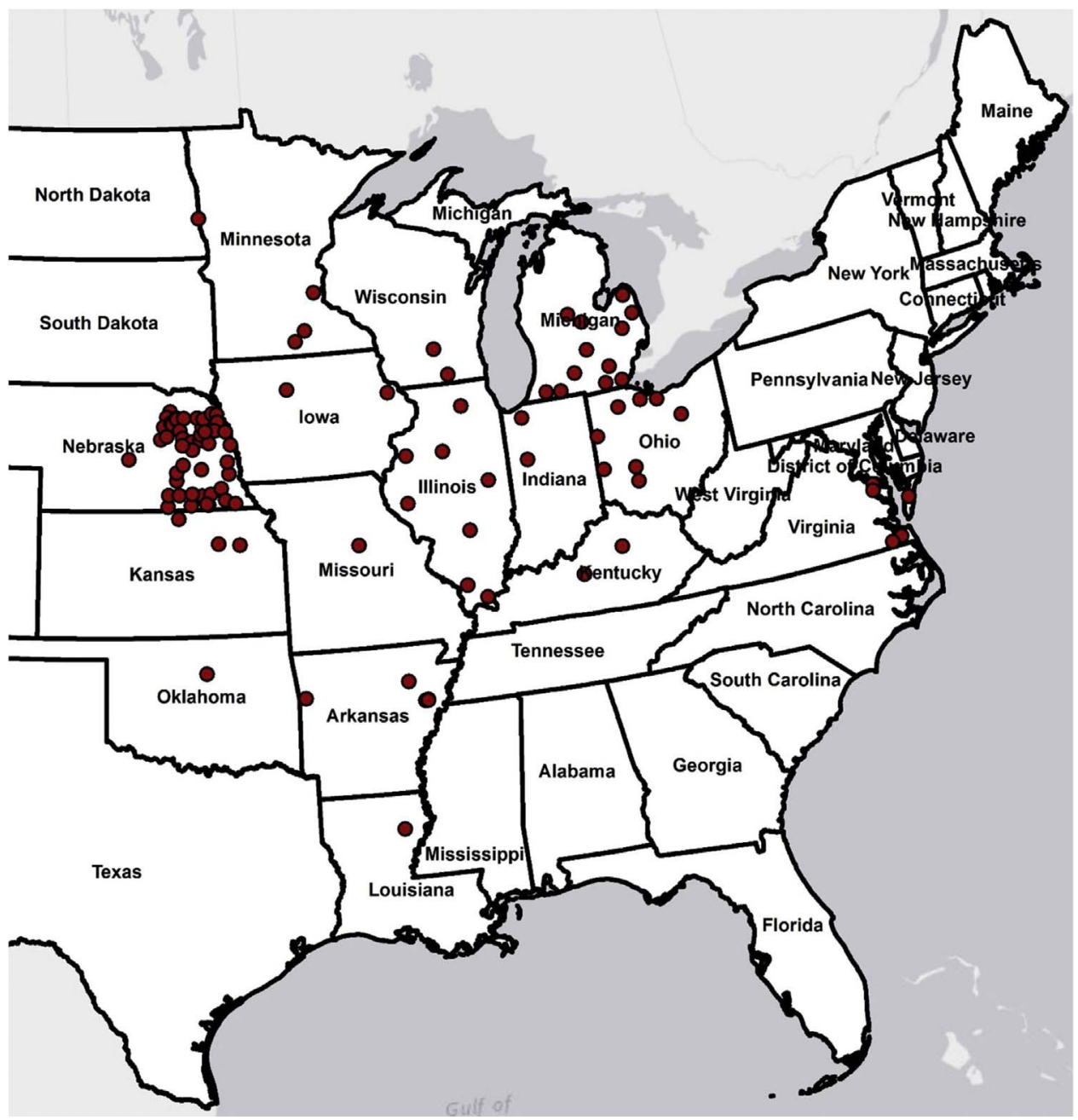

Fig. 1. Locations of individual studies from which data were combined into a single database. 
experiments established from 1996 to 2016, at 105 locations within 16 states across the USA (Fig. 1). The states were: Arkansas, Iowa, Illinois, Indiana, Kansas, Kentucky, Louisiana, Michigan, Minnesota, Missouri, Ohio, North Dakota, Nebraska, Oklahoma, Virginia, and Wisconsin. Raw data from many sources (Freeborn et al., 2001; Wortmann et al., 2012; Attia et al., 2015; Staton et al., 2011-2016; Orlowski et al., 2016; Mourtzinis et al., 2017) as well as several sources of previously unpublished data were included in our analysis. The resultant database consisted of 5991 plot-specific yield data derived from a total of 207 environments (experiment $\times$ year). All individual trials were replicated within their respective environments.

For every experiment, the data were coded for the four N-related variables and for five major management variables (hereafter called "MM".) The $\mathrm{N}$ variables were:

(a) $\mathrm{N}$-applications (i.e., zero $\mathrm{N}$ control, one, or two applications),

(b) N-method (i.e., zero $\mathrm{N}$ control, applied to the soil surface, soil-incorporated, foliar-applied, or a combination of these methods),

(c) $\mathrm{N}$-timing [i.e., zero $\mathrm{N}$ control, pre-plant applied (pP), applied at planting $(\mathrm{P})$, or at a vegetative stage $(\mathrm{Vn})$, or at a reproductive stage (Rn), or split-applied at planting then at an Rn stage (PR), or split applied at two Rn stages (RR)], and

(d) N-rate $\left(0-560 \mathrm{~kg} \mathrm{ha}^{-1}\right)$.

The MM variables considered in our analysis were: irrigation (irrigated or rainfed), tillage (conventional or reduced tillage), previous crop (cereal or legume), seeding rate (range of 297,000 to 618,000 seeds $\mathrm{ha}^{-1}$ ), and crop row width (range of $18-102 \mathrm{~cm}$ ). The reduced tillage category ( $64 \%$ of total plots) consisted of trials with notill (96\%), mulch (2.6\%), strip-till (0.6\%), disk (0.4\%), and vertical tillage $(0.4 \%)$. The prior cereal crops included corn (Zea mays L.) (89\%), wheat (Triticum aestivum L.) (10\%), rice (Oryza sativa L.) (1.4\%), and sorghum [Sorghum bicolor (L.) Moench] (0.6\%), whereas the prior legume crops were either soybean (97\%) or groundnut (Arachis hypogaea L.) (3\%).

Among all experiments, most plots received a single $\mathrm{N}$ application, though ca. $13 \%$ of total plots did receive a split $\mathrm{N}$ application (Fig. 2A). Nitrogen application on the soil surface was the most common method, whereas foliar, soil incorporated, and other combinations were used less frequently (Fig. 2B).

Similarly, a single $\mathrm{N}$ application during an Rn stage was the most common timing, with pre-planting (pP) and split $\mathrm{N}$ applications (PR, $\mathrm{RR}$ ) used less frequently (Fig. 2C). The $\mathrm{N}$ rate varied from 0 to
$560 \mathrm{~kg} \mathrm{ha}^{-1}$, with mean and median rates of 74 and $45 \mathrm{~kg} \mathrm{ha}^{-1}$, respectively (Fig. 2D). These results show that across all experiments, the most common $\mathrm{N}$ treatment involved a single, surface-applied $\mathrm{N}$ application during reproductive growth.

Substantial variation of MM practices was also observed among the experiments (Figs. 3A-C and $4 \mathrm{~A}$ and B); the majority were not irrigated, were managed with reduced tillage practices, and soybean followed a cereal crop. Seeding rates ranged between $297,000-618,000$ seeds ha ${ }^{-1}$, with 404,000 and 408,000 seeds ha ${ }^{-1}$ signifying the mean and median rates, respectively. Row widths ranged between 18-102 cm, with 55 and $38 \mathrm{~cm}$ signifying the mean and median widths, respectively.

\subsection{Data analysis}

\subsubsection{Hierarchical modeling}

In all experiments, the predominant, and often, only dependent variable, was the $\mathrm{N}$-rate. All other variables imposed across the various experiments were not applied in a randomized manner within and among replications of each experiment, and therefore, no structure (e.g., nested) among these existed. Due to the high degree of variability of management practices $(\mathrm{N} \times \mathrm{MM})$ among all experiments, the four $\mathrm{N}$ variables of interest were analyzed separately and the yield variability due to the MM variables was attributed to the experiment $\times$ year interaction. This approach allowed us to create a nested structure of the $\mathrm{N}$ variables within environments.

Multilevel modeling was used to quantify $\mathrm{N}$ and non- $\mathrm{N}$ related sources of the observed soybean yield variability, following the approach described by Bell et al. (2013). In short, we fitted a three-level unconditional (random effect) hierarchical nested linear model to assess overall soybean yield variability (intercept - level 1), the variability among years (level 2), and variability among environment (experiment $\times$ year combinations - level 3) using PROC GLIMMIX in SAS Version 9.4 (SAS Institute Inc., Cary, NC). Mean soybean yield values corresponding to year, experiment within year [experiment (year)], and replication within experiment $\times$ year [rep (experiment year)] were the variance components. Then, to examine the hypothesis that yields were affected by different $\mathrm{N}$ management variables (i.e., $\mathrm{N}$-applications number, N-method, $\mathrm{N}$-timing, and $\mathrm{N}$-rate), three-level conditional (mixed effect) hierarchical nested linear models were used to analyze each of these $\mathrm{N}$ variables separately. In all models, each $\mathrm{N}$ variable was treated as a fixed effect (level 1), whereas year (level 2), experiment (year), rep (experiment year), and $\mathrm{N}$ (experiment year) (level 3) were
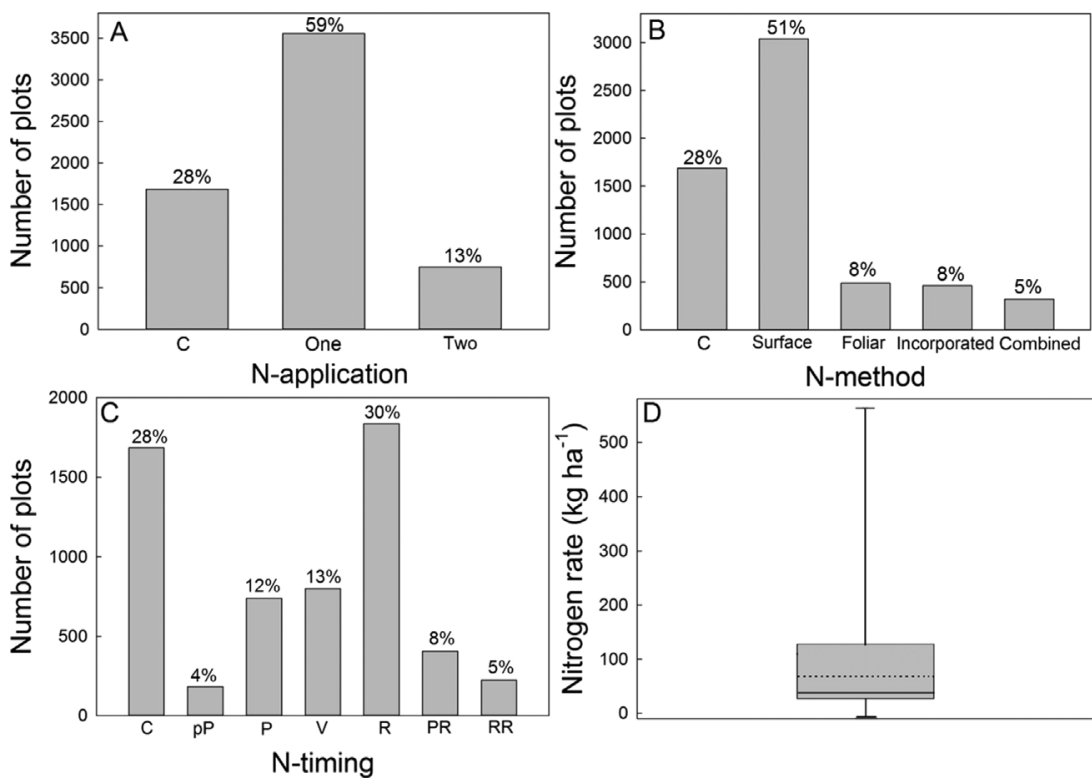

Fig. 2. Description of N-related management practices applied across all individual studies: A) $\mathrm{N}$-application, B) $\mathrm{N}$-method, C) $\mathrm{N}$-timing, and D) N-rate $\left(\mathrm{kg} \mathrm{ha}^{-1}\right)$. Note: $\mathrm{C}$ - no $\mathrm{N}$ control, One - single $\mathrm{N}$ application, Two - split N applications, Surface - N applied on soil surface, Foliar - N foliar-applied, Incorporated - N soil-incorporated, Combined - N surface- and foliar-applied, pP - N pre-plant applied, $\mathrm{P}$ $-\mathrm{N}$ applied at planting, $\mathrm{V}-\mathrm{N}$ applied at a vegetative $(\mathrm{Vn})$ stage, $\mathrm{R}-\mathrm{N}$ applied at a reproductive ( $\mathrm{Rn})$ stage, $\mathrm{PR}-\mathrm{N}$ split-applied between planting and a Rn stage, RR - N split-applied between two Rn stages. The numbers on top of each bar indicate the percentage of plots that received the same treatment. The central rectangle of the boxplot spans the first quartile to the third input quartile. The solid line inside the rectangle is the median, the dotted line is the mean, and vertical lines above and below the box extend to the minimum and maximum values, respectively. 


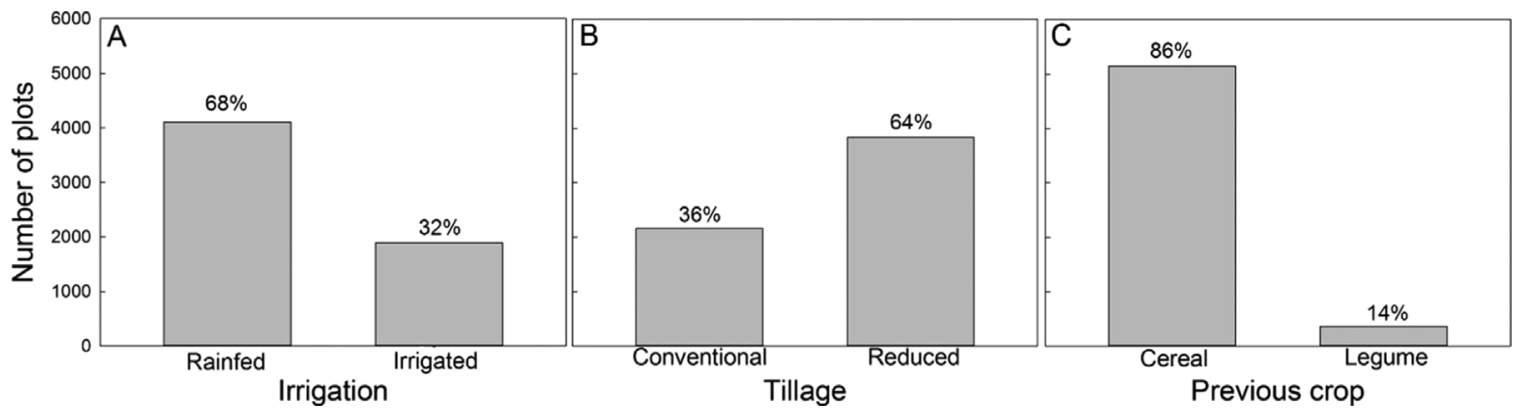

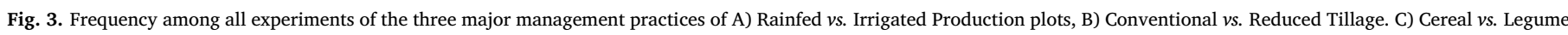
as the Previous Crop. Note: The numbers on top of each bar indicate the percentage of plots that received the same treatment.
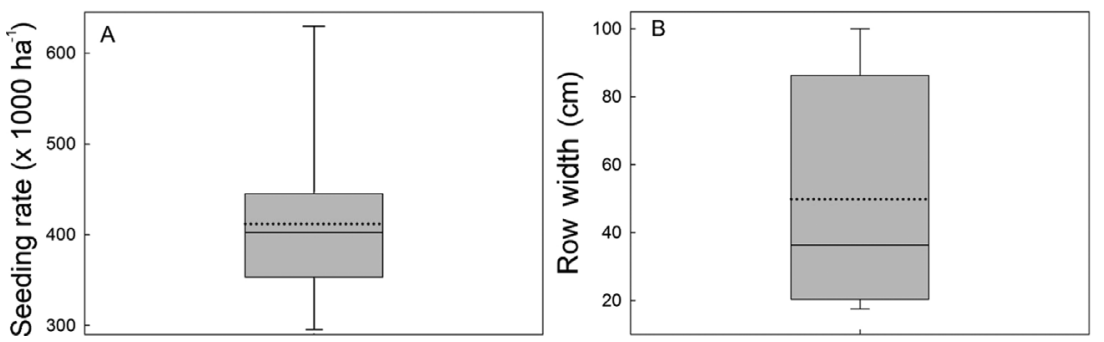

Fig. 4. Range among all experiments for the numerical value of two MM practices of A) Seeding Rate $\left(\times 1000 \mathrm{ha}^{-1}\right)$, and B) Row With $(\mathrm{cm})$. The central rectangle of the boxplots spans the first quartile to the third input quartile. The solid line inside the rectangle is the median, the dotted line is the mean, and the vertical lines above and below the box extend to the minimum and maximum values, respectively. considered to be random effects. The assumption that an $\mathrm{N}$ factor had a variable effect on both soybean mean yield and the variance components was tested by fitting heterogenous variance models. In these models, and for all four $\mathrm{N}$ variables, soybean yield variance components associated with experiment $\times$ year were allowed to vary among levels of each $\mathrm{N}$ variable.

To estimate the parameter-specific associated yield variability, the interclass correlation coefficient (ICC) was used as in Eq. (1):

ICC $=\sigma^{2}$ effect $/ \sigma^{2}$ total

In Eq. (1), " $\sigma^{2}$ " denotes the yield variance.

To test the average effect of N-rate across all experiments, the linear and quadratic forms of $\mathrm{N}$-rate were included in the model as fixed effects using the same aforementioned random effects. The N-rate, which was associated with maximum across-environment average yield, was estimated by calculating the first derivative of the quadratic relationship.

Among all the described fitted models, the most appropriate for each $\mathrm{N}$ variable was chosen by comparing their Akaike information criteria (AIC) with the -2 Res Log Likelihood values. Due to the treatment imbalance among experiments, the Kenward-Roger degrees of freedom approximation (Kenward and Roger, 1997) was used in all models. This approximation adjusts for small sample bias and is wellsuited for multilevel models with unbalanced designs (Bell et al., 2013). The level of significance was set to $5 \%$ (alpha $=0.05$ ), and the Tukey adjustment was used for multiple pairwise means comparisons.

\subsubsection{Conditional inference trees}

Application of MM decisions having a large effect on soybean yield (e.g., irrigation) varied among the experiments included in this study. Taking into account their effect on yield in a single model along with the $\mathrm{N}$ variables allows for identification of important interactions. However, as noted above, these factors were not applied in the original trial in a randomized manner, nor were all their levels replicated within experiments. Due to the lack of treatment random allocation and lack of proper replication of these factors, use of traditional linear models (e.g., analysis of variance or multiple linear regression) is not appropriate. Therefore, we used conditional inference regression trees methodology, within the partykit package in R (R development Core team, 2016), to identify the effects of MM decisions and $\mathrm{N}$ variable interactions on soybean yield across the examined region. This method does not make statistical distribution assumptions, can handle categorical and continuous explanatory variables, is robust to outliers, multicollinearity, heteroscedasticity, and can reveal variable interactions (Tittonel et al., 2008). Moreover, there are no bias and overfitting issues as in regression trees, and this method estimates a relationship among several variables by binary recursive partitioning in a conditional inference framework (Hothorn et al., 2006).

In the first step, the algorithm tests the global null hypothesis of independence between the response variable (i.e., yield) and any of the input variables (i.e., $\mathrm{N}$ and $\mathrm{MM}$ variables). If the hypothesis cannot be rejected, the algorithm stops, otherwise the algorithm selects the input variable with strongest association to the response. The association is measured by a p-value which corresponds to an association test for the partial null hypothesis of a single input variable and the response. Then, a binary split is implemented in the selected variable (node) and all steps are recursively repeated. The terminal node accounts for the final subset of plot-specific yields. The result of this procedure is a tree-like graph where intermediate and terminal nodes are defined according to pre-specified criteria. In this analysis, the criterion for the independence test was based on univariate p-values (alpha $=0.05$ ). Additionally, to ensure adequate power at all steps, each intermediate node had to account for a minimum of 1200 plots $(20 \%$ of total observations), and a terminal node should contain a minimum of 400 plots (7\% of total observations). To qualify a variable for a split, all aforementioned criteria had to be met. To avoid overfitting and enhance interpretability, the maximum tree depth was set to 20 nodes. The explanatory power of the model was assessed by calculating the coefficient of determination $\left(\mathrm{R}^{2}\right)$ and root mean square error (RMSE). Allowing the development of larger trees and terminal nodes with a smaller number of plots would increase the predictive ability of the models (greater $\mathrm{R}^{2}$ ); however, such overfitting would diminish interpretability of the results.

Sensitivity of the results due to the chosen criteria was assessed by repeating the analysis with different combinations of minimum number of plots per intermediate node (10-30\% of total observations), per terminal node (5-15\% of total observations), and tree depth (up to 30 nodes). In only a few large models (larger than 20 nodes) there were small variations in the selected variables; however, the fit of the model was not substantially improved (greatest $\mathrm{R}^{2}$ improvement was $3 \%$ ). 
Therefore, the most parsimonious and robust model was selected.

\section{Results}

Among all experiments, the largest yield variability (intercept only) was associated with the experiments' within year effect (Table 1), which accounted for $68 \%$ of total yield variability (ICC $=0.68$ ). Effect of year accounted for $11 \%$ of yield variability, whereas just $3 \%$ of variability was associated with the within-experiment variation [Rep (experiment year)]. The amount of unexplained yield variability (residual) was $18 \%$ of total. Variable MM practices among experiments likely influenced soybean yield in a manner that resulted in the unexplained variability. The yield variance decomposition, when controlling for $\mathrm{N}$-applications, $\mathrm{N}$-method, $\mathrm{N}$-timing, and $\mathrm{N}$-rate, was similar to the unconditional model (intercept only) (Table 1). Only a small fraction $(<1 \%)$ of total variability was attributed to each $\mathrm{N}$ variable within experiment $\times$ year. These results show the small N-related effect on soybean yield relative to other sources of variability (e.g., weather, soil, and MM decisions) which, by design, were assumed to be accounted for in the experiment $\times$ year interaction.

The among-experiment average effect of $\mathrm{N}$-application on soybean yield was significant (Fig. 5A). A single $\mathrm{N}$ application was $60 \mathrm{~kg} \mathrm{ha}^{-1}$ greater yielding than the control, and the split $\mathrm{N}$ application also resulted in $110 \mathrm{~kg} \mathrm{ha}^{-1}$ greater seed yield than zero $\mathrm{N}$ plots, as did the split $\mathrm{N}$ application with more than one application method, which yielded $120 \mathrm{~kg} \mathrm{ha}^{-1}$ more than non-treated plots (Fig. 5B). Split application of $\mathrm{N}$ with more than one application method (e.g., surface and foliar) resulted in the greatest average soybean seed yield $\left(4,180 \mathrm{~kg} \mathrm{ha}^{-1}\right)$, but not significantly more compared to when $\mathrm{N}$ was surface- or foliar-applied (Fig. 5B). Nevertheless, the yields attained with the combined $\mathrm{N}$-methods of application were significantly greater than the yields generated from non-treated plots and soil-incorporated $\mathrm{N}$, respectively.

Small differences were observed among different $\mathrm{N}$ application timings (Fig. 5C). The greatest average yield was observed for PR, which was significantly greater than control and a single $\mathrm{N}$ application during Rn. Nevertheless, the 60 to $180 \mathrm{~kg} \mathrm{ha}^{-1}$ yield differences from the other $\mathrm{N}$ application timings were not statistically different. Presumably, the large within-treatment yield variability (Table 2), which is likely attributed to the effect of the MM practices on soybean yield, diminished the yield differences among the different $\mathrm{N}$ application timings.

Soybean yield response to $\mathrm{N}$-rate was quite variable at the lower $\mathrm{N}$ rates (up to $c a .125 \mathrm{~kg} \mathrm{ha}^{-1}$ ), for which there were many experimental data points (Fig. 5D), but when coupled with the fewer data points at the higher $\mathrm{N}$ rates, the use of all experimental data generated a seconddegree $\mathrm{N}$ polynomial function that was significant $(\mathrm{p}=0.0297)$, and it projected the $\mathrm{N}$ rate of $340 \mathrm{~kg} \mathrm{ha}^{-1}$ for maximization of soybean yield. The large yield differences among individual experiments where a similar $\mathrm{N}$ rate was applied was attributed to in-season weather variability among the diverse growing environments (e.g., north $v s$. south), and to MM practice differences. These results suggest that other, non-N practices might affect soybean yield alone, or in interaction with $\mathrm{N}$ decisions. Nevertheless, in most individual environments, the effect of a greater $\mathrm{N}$-rate on soybean yield was not significant (Fig. 6). From the 207 environments included in the analysis, only 13 of the $\mathrm{N}$ slopes were significant $(p<0.05)$ with an estimated yield increase of 9-30 kg ha ${ }^{-1}$ for every $10 \mathrm{~kg}$ of applied N. These environments included irrigated experiments in Arkansas and rainfed experiments in Illinois, North Dakota, and Ohio. Among these environments, yield ranged from 3,390 to $5,760 \mathrm{~kg} \mathrm{ha}^{-1}$. This result implies that despite the yield differences among environments, soybean response to $\mathrm{N}$ was minimal across the examined regions.

To identify and quantify the management variables that influenced soybean yield across all experiments, the fitted conditional inference tree included four MM variables (irrigation, seeding rate, tillage, and row width) and two $\mathrm{N}$ variables (N-timing and N-rate) (Fig. 7). The results of the model suggest that in irrigated experiments, a single $\mathrm{N}$ application during a Rn stage, or split $\mathrm{N}$ applications during $\mathrm{Vn}$ and $\mathrm{Rn}$ stages, or during two $\mathrm{Rn}$ stages resulted in $200 \mathrm{~kg} \mathrm{ha}^{-1}$ greater yield than the rest of the $\mathrm{N}$ timings. However, in rainfed experiments, the addition of supplemental $\mathrm{N}$ was significant only when seeding rates were $>420,000$ seeds $\mathrm{ha}^{-1}$. From the total $5991 \mathrm{~N}$-treated soybean yields, $36 \%$ were associated with such high seeding rates. In these experiments, $\mathrm{N}$ rate $>15 \mathrm{~kg} \mathrm{ha}^{-1}$ (and up to $560 \mathrm{~kg} \mathrm{ha}^{-1}$ ) at $\mathrm{P}, \mathrm{PR}, \mathrm{RR}$, and $\mathrm{V}$ growth stages resulted in $200-400 \mathrm{~kg} \mathrm{ha}^{-1}$ greater yield when compared to the other $\mathrm{N}$ timings and rates. These results indicate that non- $\mathrm{N}$ practices interact with $\mathrm{N}$ decisions and thereby affect soybean yield response to $\mathrm{N}$ application.

\section{Discussion}

States represented by the 105 locations included in our study account for $85 \%$ of the total harvested area and $86 \%$ of total USA soybean production (USDA-NASS, 2017). Hierarchical modeling and conditional inference trees were applied to a composite set of data derived from replicated experiments performed across the USA which were aimed at identifying and quantifying the effect of four $\mathrm{N}$-related management decisions on soybean seed yield. The interactive effects of these decisions with non- $\mathrm{N}$ management practices are likely to be of great interest, and thus, were also evaluated. The results obtained in our analyses have expanded on previous region-specific experiments that focused solely on one or a small subset of $\mathrm{N}$ management variables and did not account for weather, soil, and non-N management effects on soybean yield. However, our analyses provided information about the effectiveness of $\mathrm{N}$ fertilizer applications number, method, timing, and rate across a wide range of environments and cropping systems in important soybean-producing regions of the USA.

In our study, levels of $\mathrm{N}$-application, $\mathrm{N}$-method, $\mathrm{N}$ - timing, and $\mathrm{N}$ rate positively affected soybean yield across experiments. The high

Table 1

Estimation of soybean yield variance components across-experiments (Intercept), and across-experiments accounting for N-application, $\mathrm{N}$-timing, $\mathrm{N}$-method, and $\mathrm{N}$-rate.

\begin{tabular}{|c|c|c|c|c|c|c|c|c|c|c|}
\hline \multirow{4}{*}{$\begin{array}{l}\text { Random effect } \\
\text { Covariance parameter } \\
\text { Year }\end{array}$} & \multicolumn{10}{|c|}{ Fixed effect } \\
\hline & \multirow{2}{*}{\multicolumn{2}{|c|}{ Intercept }} & \multirow{2}{*}{\multicolumn{2}{|c|}{$\mathrm{N}$-application }} & \multirow{2}{*}{\multicolumn{3}{|c|}{$\begin{array}{l}\text { N-method N-timing } \\
\text { Estimate (standard error) }\end{array}$}} & \multirow[b]{3}{*}{$(0.08)$} & \multirow{2}{*}{\multicolumn{2}{|c|}{ N-rate }} \\
\hline & & & & & & & & & & \\
\hline & 0.10 & $(0.08)$ & 0.10 & $(0.08)$ & 0.10 & $(0.08)$ & 0.11 & & 0.11 & $(0.08)$ \\
\hline Experiment (year) & 0.62 & $(0.07)$ & 0.62 & $(0.07)$ & 0.62 & $(0.07)$ & 0.63 & $(0.07)$ & 0.63 & $(0.07)$ \\
\hline Rep (experiment year) & 0.03 & $(0.003)$ & 0.03 & $(0.003)$ & 0.03 & $(0.003)$ & 0.03 & $(0.003)$ & 0.03 & $(0.003)$ \\
\hline $\mathrm{N}$-application (experiment year) & $\mathrm{NA}^{\mathrm{a}}$ & NA & 0.004 & $(0.002)$ & NA & NA & NA & NA & NA & NA \\
\hline N-method (experiment year) & NA & NA & NA & NA & 0.008 & $(0.001)$ & NA & NA & NA & NA \\
\hline $\mathrm{N}$-timing (experiment year) & NA & NA & NA & NA & NA & NA & 0.005 & $(0.002)$ & NA & NA \\
\hline N-rate (experiment year) & NA & NA & NA & NA & NA & NA & NA & NA & 0.00001 & $(0.000001)$ \\
\hline Residual & 0.16 & $(0.003)$ & 0.16 & $(0.003)$ & 0.16 & $(0.003)$ & 0.16 & $(0.003)$ & 0.16 & $(0.003)$ \\
\hline
\end{tabular}

${ }^{\text {a }}$ Not applicable. 

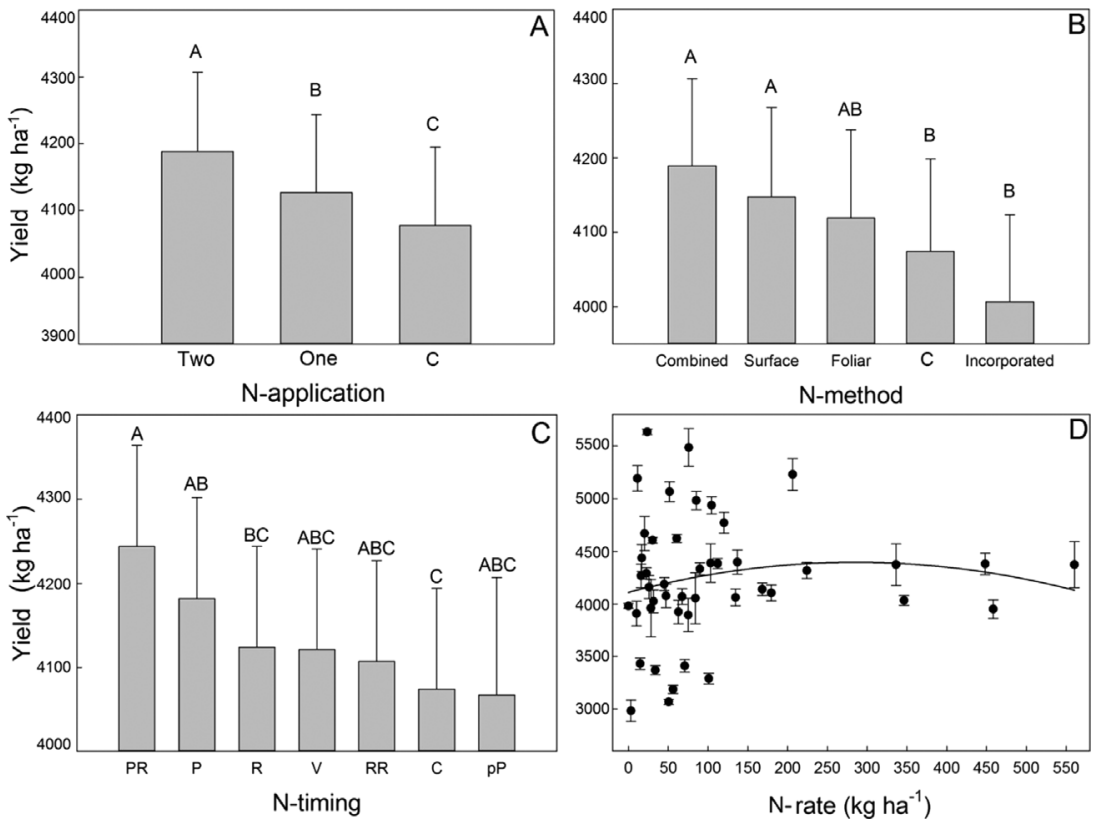

Fig. 5. Mean effect of individual $\mathrm{N}$ variables on soybean seed yield, when averaged over all experiments, for A) $\mathrm{N}$-applications, B) $\mathrm{N}$ method, C) N-timing, and D) N-rate $\left(\mathrm{kg} \mathrm{ha}^{-1}\right)$. Note: $\mathrm{C}$ - no N control, One - single N Application, Two - split N applications, C - No N control, Combined - soil surface- and foliar-applied, Surface - soil surface-applied, Foliar - foliar-applied, Incorporated - soil incorporated, PR - split applied between planting and a reproductive (Rn) stage, P - applied at planting, R - applied at a Rn stage, V applied at a vegetative (Vn) stage, RR - split applied between two Rn stages, $\mathrm{pP}$ - pre-plant applied. Vertical lines represent standard errors of the mean. Yields with the same letter were not significantly different at alpha $=0.05$.
Table 2

Soybean yield variation due to method of $\mathrm{N}$ timing across the examined region.

\begin{tabular}{llllllll}
\hline N-timing & C & P & PR & R & RR & V & pP \\
\hline CV (\%) & 25 & 25 & 19 & 21 & 20 & 21 & 15 \\
\hline
\end{tabular}

Note: $\mathrm{C}=$ No $\mathrm{N}$ application, $\mathrm{P}$ - applied at planting, $\mathrm{PR}$ - split applied between planting and a reproductive (Rn) stage, $R$ - applied at a Rn stage, RR - split-applied at two Rn stages, $\mathrm{V}$ - applied at a vegetative (Vn) stage, $\mathrm{pP}$ - pre-plant applied, CV = coefficient of variation.

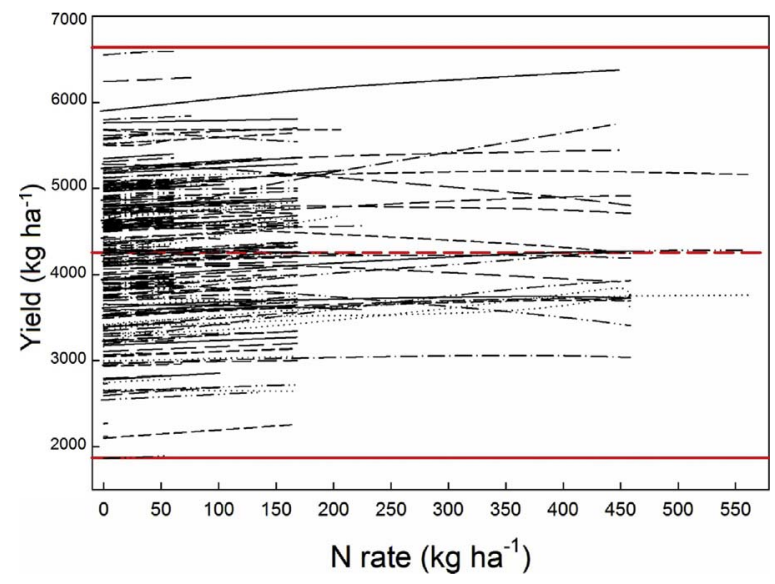

Fig. 6. Environment-specific effect of $\mathrm{N}$-rate $\left(\mathrm{kg} \mathrm{ha}^{-1}\right)$ on soybean seed yield in 207 environments (experiment $\times$ year combinations). Note: Bottom and upper solid red reference lines delineate the bottom and upper specification and the middle dashed red reference line denotes the average.

degree of variability associated with these responses supports the hypothesis that many environmental and management factors interact to affect the outcomes of $\mathrm{N}$ fertilization decisions. We suspect that these individual regional experiments did not detect consistent responses because of limitations in accounting for variability in management and environment. This limited inference space (applicable when there was just one or a few experimental trials), when combined with the small effect of $\mathrm{N}$ fertilization on yield observed in this study, likely made it difficult for the experimenters to detect $\mathrm{N}$-related management factors that intrinsically and proportionally had a relatively small effect on soybean yield. The largest source of yield variability, accounting for $68 \%$ of the total variability, was attributable to differences in climatic conditions (e.g., northern vs. southern states) and cropping systems (e.g., irrigated $v s$. rainfed experiments). When accounting for all known sources of yield variability, only a small fraction $(<1 \%)$ of total variability was explainable by each $\mathrm{N}$ variable separately. These results revealed that across the regions examined by this study, only small $\mathrm{N}$ related effects on soybean seed yield were detected $\left(<200 \mathrm{~kg} \mathrm{ha}^{-1}\right)$, which suggests that larger effects cannot be rationally expected. This result is somewhat different from Cafaro et al. (2017) who observed a seed yield benefit due to $\mathrm{N}$ application in environments with yield potential greater than $2,500 \mathrm{~kg} \mathrm{ha}^{-1}$. Nevertheless, in that study, $\mathrm{N}$ rates ranged from 330 to $870 \mathrm{~kg} \mathrm{ha}^{-1}$ which were much higher than the $\mathrm{N}$ rates that were applied in the experiments in our study. Overall, the limited responses to $\mathrm{N}$ effects in our study, as well as the costs associated with $\mathrm{N}$ application, indicate that these small positive effects would be unlikely to result in positive economic returns from $\mathrm{N}$ fertilization decisions.

The variation in soybean yield responses to the experimental trial Nfertilizer could be due to $\mathrm{N}$-response differences among cultivars (i.e., genetics), trial site differences in soil properties (i.e., initial soil $\mathrm{N}$ content, topography, texture, temperature, $\mathrm{pH}$, moisture, nutrients), growing season weather, and non-N-related crop management practices, such as irrigation, tillage, crop rotation, and planting date (Osborne and Riedell, 2006a). For example, it has been reported that soybean yield response to $\mathrm{N}$ fertilizer can be amplified by dry soil's negative effect on $\mathrm{N}$ fixation (Purcell et al., 2004; Ray et al., 2006). Indeed, the fitted conditional inference tree identified that $\mathrm{N}$-timing and $\mathrm{N}$-rate were conditional to irrigation and seeding rate. These results suggest that $\mathrm{N}$ fertilization is unlikely to significantly increase soybean seed yield across the USA, and that any local decisions to utilize $\mathrm{N}$ fertilization on soybean should take into account both local and regional climatic conditions as well as crop management practices characteristic of the region where the soybeans are produced.

\section{Conclusions}

The research findings we present here have important implications in the design of future experimental studies that aim to optimize soybean $\mathrm{N}$ management decisions. We conclude that $\mathrm{N}$ management can only be optimized when considering the cropping system because non- 


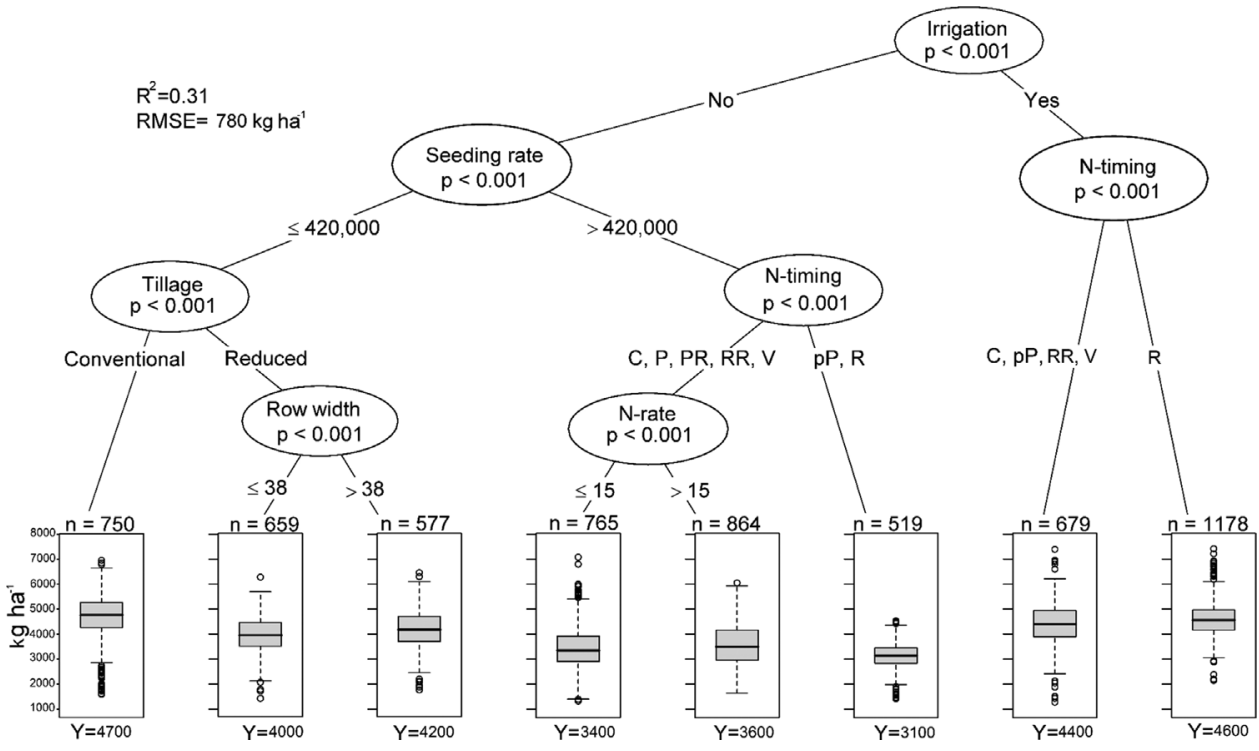

Fig. 7. Conditional inference tree across the examined region. In each boxplot, the central rectangle spans the first quartile to the third yield quartile. The solid line inside the rectangle is the mean, whose numerical value is shown at the boxplot bottom (Y). The vertical lines above and below the rectangle denote the maximum and minimum, respectively. White circles represent outlier yields. Note: $\mathrm{n}=$ number of plots, $\mathrm{Y}=$ average soybean yield within a terminal node $\left(\mathrm{kg} \mathrm{ha}^{-1}\right), \mathrm{C}-\mathrm{No} \mathrm{N}$ applied, $\mathrm{P}$ - applied at planting, PR - split-applied between planting and a reproductive (Rn) stage, RR - splitapplied between two Rn stages, $\mathrm{V}$ - applied at a vegetative (Vn) stage, pP - pre-plant applied, R - applied at a Rn stage. Seed rate (seeds ha ${ }^{-1}$ ), Row width $(\mathrm{cm})$ and N-rate $\left(\mathrm{kg} \mathrm{ha}^{-1}\right)$.

$\mathrm{N}$ management practices such as irrigation and seeding rates interacted with $\mathrm{N}$-timing and $\mathrm{N}$-rate. The large effect of environment and the small effect of $\mathrm{N}$ on soybean yield that we detected highlight the importance of developing optimal experimental designs to unravel such effects in important soybean-producing regions of not only the USA but also other soybean-producing areas. Given the growing pressure for increasing food production while minimizing the environmental footprint, it is imperative that experimenters consider environment- and cropping system-specific impacts when designing randomized trials involving all $\mathrm{N}$ decisions related to application number, method, timing, and rate.

\section{Acknowledgements}

Authors acknowledged the Wisconsin Soybean Marketing Board (WSMB), United Soybean Board (USB), and North Central Soybean Research Program (NCSRP) for their support of this project.

\section{References}

Agehara, S., Warncke, D.D., 2005. Soil moisture and temperature effects on nitrogen release from organic nitrogen sources. Soil Sci. Soc. Am. J. 69, 1844-1855.

Al-Ithawi, B., Deibert, E., Olson, R., 1980. Applied N and moisture level effects on yield, depth of root activity, and nutrient uptake by soybeans. Agron. J. 72, 827-832.

Attia, A., Shapiro, C., Kranz, W., Mamo, M., Mainz, M., 2015. Improved yield and nitrogen use efficiency of corn following soybean in irrigated sandy loams. Soil Sci. Soc. Am. J. 79, 1693-1703. http://dx.doi.org/10.2136/sssaj2015.05.0200.

Barker, D.W., Sawyer, J.E., 2005. Nitrogen application to soybean at early reproductive development. Agron. J. 97, 615-619.

Beard, B.H., Hoover, R.M., 1971. Effect of nitrogen on nodulation and yield of irrigated soybeans. Agron. J. 63, 815-816.

Bellaloui, N., Bruns, H.A., Abbas, H.K., Mengistu, A., Fisher, D.K., Reddy, K.N., 2015. Effects of row-type, row-spacing, seeding rate, soil-type, and cultivar differences on soybean seed nutrition under us Mississippi Delta conditions. PLoS One 10, e0129913.

Bell, A.B., Ene, M., Smiley, W., Scoeneberger, J.A., 2013. A Multilevel Model Primer Using SAS ${ }^{\circ}$ PROC MIXED. SAS Global Forum. Statistics and Data Analysis. Paper 433. http://support.sas.com/resources/papers/proceedings13/433-2013.pdf (Accessed 15 September 2017)

Bender, R.R., Haegele, J.W., Below, F.E., 2015. Nutrient uptake, partitioning, and remobilization in modern soybean varieties. Agron. J. 107, 563-573. http://dx.doi. org/10.2134/agronj14.0435.

Brevedan, R., Egli, D., Leggett, J., 1978. Influence of N nutrition on flower and pod abortion and yield of soybeans. Agron. J. 70, 81-84.

Cafaro, La, N., Menza Monzon, J.P., Specht, J.E., Grassini, P., 2017. Is soybean yield limited by nitrogen supply? Field Crops Res. 213, 204-212. http://dx.doi.org/10. 1016/j.fcr.2017.08.009.

Fehr, W.R., Caviness, C.E., 1977. Stages of Soybean Development. Coop. Ext. Serv., Agric. and Home Economics Exp. Stn., Iowa State Univ., Ames.

Freeborn, J.R., Holshouser, D.L., Alley, M.M., Powell, N.L., Orcutt, D.M., 2001. Soybean yield response to reproductive stage soil-applied nitrogen and foliar-applied boron. Agron. J. 93, 1200-1209.
Gaspar, A., Laboski, C., Naeve, S., Conley, S., 2017. Dry matter and nitrogen uptake, partitioning, and removal across a wide range of soybean seed yield levels. Crop Sci. 57, 1-13. http://dx.doi.org/10.2135/cropsci2016.05.0322.

George, T., Singleton, Paul W., Ben Bohlool, B., 1988. Yield, soil nitrogen uptake, and nitrogen fixation by soybean from four maturity groups grown at three elevations. Agron. J. 80, 563-567.

Harper, J., 1974. Soil and symbiotic nitrogen requirements for optimum soybean production. Crop Sci. 14, 255-260.

Harper, J., Gibson, A., 1984. Differential nodulation tolerance to nitrate among legume species. Crop Sci. 24, 797-801.

Harper, J.E., Cooper, R.L., 1971. Nodulation response of soybeans (Glycine max L. Merr.) to application rate and placement of combined nitrogen. Crop Sci. 11, 438-440.

Hothorn, T., Hornick, K., Zeileis, A., 2006. Unbiased recursive partitioning: a conditional inference framework. J. Comput. Graphical Stat. 15, 651-674. http://dx.doi.org/10. 1198/106186006X133933.

Kenward, M.G., Roger, J.H., 1997. Small sample inference for fixed effects from restricted maximum likelihood. Biometrics 53, 983-997.

Lamb, J., Rehm, G., Severson, R., Cymbaluk, T., 1990. Impact of inoculation and use of fertilizer nitrogen on soybean production where growing seasons are short. J. Prod. Agric. 3, 241-245.

Mastrodomenico, A.T., Purcell, L.C., 2012. Soybean nitrogen fixation and nitrogen remobilization during reproductive development. Crop Science 52, 1281-1289.

McCoy, J.M., 2016. Soybean Yield and Biomass Response to Supplemental Nitrogen Fertilization. M.S. Thesis. Mississippi State Univ., Starkville.

Mourtzinis, S., Marburger, D., Gaska, J.M., Diallo, T., Lauer, J., Conley, S.P., 2017. Corn, soybean, and wheat yield response to crop rotation, nitrogen fertilization, and foliar fungicide use. Crop Sci. 57, 983-992. http://dx.doi.org/10.2135/cropsci2016.10. 0876.

Orlowski, J.M., Haverkamp, B.J., Laurenz, R.G., Marburger, D.A., Wilson, E.W., Casteel, S.N., Conley, S.P., Naeve, S.L., Nafziger, E.D., Roozeboom, K.L., Ross, W.J., Thelen, K.D., Lee, C.D., 2016. High-input soybean management systems affect soybean yield, yield components, and economic break-even probabilities. Crop Sci. 56, 1988-2004. http://dx.doi.org/10.2135/cropsci2015.10.0620.

Osborne, S., Riedell, W., 2006a. Soybean growth response to low rates of nitrogen applied at planting in the northern Great Plains. J. Plant Nutr. 29, 985-1002.

Osborne, S., Riedell, W., 2006b. Starter nitrogen fertilizer impact on soybean yield and quality in the Northern Great Plains. Agron. J. 98, 1569-1574.

Purcell, L.C., King, C.A., 1996. Drought and nitrogen source effects on nitrogen nutrition, seed growth, and yield in soybean. J. Plant Nutr. 19, 969-993.

Purcell, L.C., Serraj, R., Sinclair, T.R., De, A., 2004. Soybean N fixation estimates, ureide concentration, and yield responses to drought. Crop Sci. 44, 484-492.

Ray, J.D., Heatherly, L.G., Fritschi, F.B., 2006. Influence of large amounts of nitrogen on nonirrigated and irrigated soybean. Crop Sci. 46, 52-60.

Salvagiotti, F., Cassman, K.G., Specht, J.E., Walters, D.T., Weiss, A., Dobermann, A., 2008 Nitrogen uptake, fixation and response to fertilizer $\mathrm{N}$ in soybeans: a review. Field Crops Res. 108, 1-13.

Salvagiotti, F., Specht, J.E., Cassman, K.G., Walters, D.T., Weiss, A., Dobermann, A., 2009. Growth and nitrogen fixation in high-yielding soybean: impact of nitrogen fertilization. Agron. J. 101, 958-970.

Scharf, P.C., Wiebold, W.J., 2003. Soybean yield responds minimally to nitrogen applications in Missouri. Crop Manage. 2, 1. http://dx.doi.org/10.1094/CM-2003-111701-RS.

Schmitt, M.A., Lamb, J.A., Randall, G.W., Orf, J.H., Rehm, G.W., 2001. In-season fertilizer nitrogen applications for soybean in Minnesota. Agron. J. 93, 983-988.

Sinclair, T.R., de Wit, C.T., 1975. Comparative analysis of photosynthesis and nitrogen requirements in the production of seeds by various crops. Science $189,565-567$. http://dx.doi.org/10.1126/science.189.4202.565. 
Sorensen, R., Penas, E., 1978. Nitrogen fertilization of soybeans. Agron. J. 70, 213-216. Stanford, G., Frere, M.H., Schwaninger, D.H., 1973. Temperature coefficient of soil nitrogen mineralization. Soil Sci. 115, 321-323.

Stanford, G., Epstein, E., 1974. Nitrogen mineralization-water relations in soils. Soil Sci. Soc. Am. J. 38, 103-107.

Stanford, G., Carter, J.N., Westermann, D.T., Meisinger, J.J., 1977. Residual nitrate and mineralizable soil nitrogen in relation to nitrogen uptake by irrigated sugarbeets. Agron. J. 69, 303-308.

Starling, M.E., Wood, C., Weaver, D.B., 1998. Starter nitrogen and growth habit effects on late-planted soybean. Agron. J. 90, 658-662.

Staton, M.J., Reinholt, K., Boring, T., Seamon, M., 2011-2016. Soybean management and research technologies (SMaRT) on-farm research reports. . http://michigansoybean. org/checkoff-at-work/production/ (Accessed 15 September 2017).

Stone, L., Whitney, D., Anderson, C., 1985. Soybean yield response to residual NO 3-N and applied N. Plant Soil 84, 259-265.

Thibodeau, P.S., Jaworski, E.G., 1975. Patterns of nitrogen utilization in the soybean. Planta 127, 133-147.

Tittonel, P., Shepherd, K.D., Vanlauwe, B., Giller, K.E., 2008. Unravelling the effects of soil and crop management on maize productivity in smallholder agricultural systems of western Kenya-An application of classification and regression tree analysis. Agric. Ecosyst. Environ. 123, 137-150. http://dx.doi.org/10.1016/j.agee.2007.05.005.

USDA-NASS, 2017. USDA-National Agricultural Statistics Service (NASS), Crop Production Summary. http://usda.mannlib.cornell.edu/usda/current/CropProdSu/ CropProdSu-01-12-2017.pdf (Accessed 15 September 2017).

Welch, L., Boone, L., Chambliss, C., Christiansen, A., Mulvaney, D., Oldham, M., Pendleton, J., 1973. Soybean yields with direct and residual nitrogen fertilization. Agron. J. 65, 547-550.

Wesley, T., Lamond, R., Martin, V., Duncan, S., 1998. Effects of late-season nitrogen fertilizer on irrigated soybean yield and composition. J. Prod. Agric. 11, 331-336.

Wood, C., Torbert, H., Weaver, D., 1993. Nitrogen fertilizer effects on soybean growth, yield, and seed composition. J. Prod. Agric. 6, 354-360.

Wortmann, C.S., Shapiro, C.A., Ferguson, R., Mainz, M., 2012. Irrigated soybean can have a small response to nitrogen applied during early reproductive growth. Crop Manage. http://dx.doi.org/10.1094/CM-2012-0126-01-RS.

Zapata, F., Danso, S.K.A., Hardarson, G., Fried, M., 1987. Time course of nitrogen fixation in field-grown soybean using nitrogen-15 methodology. Agron. J. 79, 172-176. 